\title{
The independent and interactive effects of snail grazing and nutrient enrichment on structuring periphyton communities
}

\author{
Jane C. Marks \& Rex L. Lowe ${ }^{1}$ \\ Department of Biological Sciences, Bowling Green State University, Bowling Green, OH 43403, USA; \\ ${ }^{1}$ The University of Michigan Biological Station, Pellston, MI 49769, USA
}

Received 9 June 1988; in revised form 18 October 1988; accepted 2 November 1988

Key words: periphyton, nutrients, grazing, snails, community structure

\begin{abstract}
We investigated the independent and interactive effects of nutrient enrichment and snail grazing on structuring periphyton communities in a northern temperate lake. Nutrient releasing substrates and grazer enclosures were used to simultaneously manipulate nutrient availability and herbivory. Periphyton was allowed 18 days to accrue before grazers (Elimia livescens $=$ Goniobasis livescens) were introduced.

Addition of nitrogen and phosphorus caused a significant increase in biovolume $(\mathrm{p}<0.001)$, whereas grazing had no significant effect on biovolume but resulted in a shift in species composition. Four taxa were largely responsible for the increase in biovolume on the nutrient enriched substrates: Oedogonium sp, Stigeoclonium tenue, Navicula radiosa var. radiosa and Navicula radiosa var. tenella. By the 28th day, nutrient enrichment caused a shift from a community dominated by diatoms (Bacillariophyceae) to a community dominated by green algae (Chlorophyceae). Blue green algae (Myxophyceae) maintained an equal proportion in high and low-nutrient regimes.

Grazing had a more pronounced effect on altering community composition on the nutrient enriched substrates than on the unenriched substrates. Grazing caused a decrease in diversity and an increase in dominance by green algae on the nutrient enriched substrates. The relative biovolume of green algae increased from $64 \%$ to $93 \%$ on grazed substrates, due to the significant increase in relative abundance of Stigeoclonium tenue. This taxon has both prostate basal cells and erect filamentous cells. The ratio of basal: filamentous cells increased from 4.7 to 5.2 with grazing, suggesting that the heretotrichous growth form of Stigeoclonium tenue is adapted to grazing by virtue of the basal cells which are able to adhere to the substratum and resist being grazed.
\end{abstract}

\section{Introduction}

Aquatic ecologists have become increasingly aware of the importance of periphyton as key primary producers in lakes (Loeb et al., 1983; Wetzel, 1964). Because periphyton has not been as thoroughly studied as planktonic algae, mecha- nisms regulating species diversity and community structure in developing periphyton communities are poorly known. Two factors known to effect periphyton composition are nutrients and grazing.

Addition of limiting nutrients to periphyton increases algal biomass (Cuker, 1983, Fairchild et al., 1985). High nutrient levels can cause a shift 
from communities dominated by diatoms to communities dominated by green filaments (Cattaneo, 1987; Fairchild et al., 1985). The physiognomy of the community often changes from being dominated by prostate forms to dominance by large filaments and stalked diatoms. In addition, nutrient enhancement can accelerate the successional process by causing a more rapid replacement of species (Fairchild \& Lowe, 1984).

Grazing can have the opposite effect on these parameters. Prior studies on the effect of grazers on periphyton have shown that grazers can substantially reduce periphyton biomass (Dickman, 1968; Kehde \& Wilhm, 1972). The physiognomy of a highly grazed periphyton community contrasts with that of a nutrient enriched community. Grazed communities are often dominated by either prostrate species, which adhere tightly to the substrate, or by small understory species which can avoid being grazed by virtue of their size (Hunter, 1980; Hunter \& Russell-Hunter, 1983; Sumner \& McIntire, 1982). Studies have shown that highly grazed periphyton has a low carbon: nitrogen ratio $(C / N)$ which is also characteristic of periphyton experiencing rapid turnover during early succession(Hunter, 1980; McMahon et al., 1974). In addition, it has been observed via oxygen evolution experiments that grazed periphyton has accelerated turnover rates (Lamberti \& Resh, 1983). Thus, it has been demonstrated that grazing can maintain periphyton communities in physiologically earlier successional stages. However, it is not clear if grazing also maintains communities in early successional stages in terms of species composition (Hoagland et al., 1982).

Because of the apparent contrasting effects of nutrient addition and herbivory we were interested in investigating the independent and interactive effects of nutrient enrichment and grazing on periphyton communities. Thus, the present study was conducted to answer the following questions: 1. How do nutrient enrichment and grazing independently affect biomass, diversity, and taxonomic composition of periphyton in a northern temperate lake? 2. Does grazing have the same effect on nutrient-stimulated and control periphyton communities? 3. Can grazing maintain communities at an early successional stage in terms of species composition?

\section{Materials and methods}

\section{Experimental design}

The study site for this experiment was Douglas Lake in Northern Michigan. Douglas lake is a hardwater, mesotrophic lake with a surface area of $15.2 \mathrm{~km}^{2}$. This study was conducted in the littoral zone at a depth of 1 meter.

Two different nutrient levels were established by using nutrient diffusing substrates as described by Fairchild \& Lowe (1984). Eight substrates were enriched using a 0.05 molar solution of $\mathrm{Na}_{2} \mathrm{HPO}_{4}$ and 0.5 molar solution of $\mathrm{NaNO}_{3}$ in $2 \%$ agar. These are referred to as the high-nutrient treatments. Eight substrates were not enriched and consisted of $2 \%$ agar in distilled water. These are the low-nutrient treatments and reflect ambient nutrient conditions in Douglas Lake. Screens for enclosing or excluding grazers were made for each substrate by stapling a cylinder of aluminum wire screening with $1 \mathrm{~mm}$ openings $3 / 4$ of the way around the top of each exclosure while the remainder was safety pinned shut. Screens were secured in the sediments with tent stakes (Fig. 1).

The substrates with screens were placed randomly in the lake study site on June 17, 1987. Periphyton colonized the substrates for 18 days at which time two high-nutrient substrates and two low-nutrient substrates were removed. These 4 substrates constitute the high and low-nutrient starting communities. Snails (Elimia livescens) were collected from the littoral zone in Douglas Lakc. Four snails were added to 3 of the 6 remaining high-nutrient substrates and 4 snails were added to 3 of the 6 remaining low-nutrient substrates. On day 20, 4 more snails were added to the 6 grazed substrates to increase the impact of snails on the periphyton community. On day 28 the substrates were removed and algae were scraped from the pots as described by Fairchild 


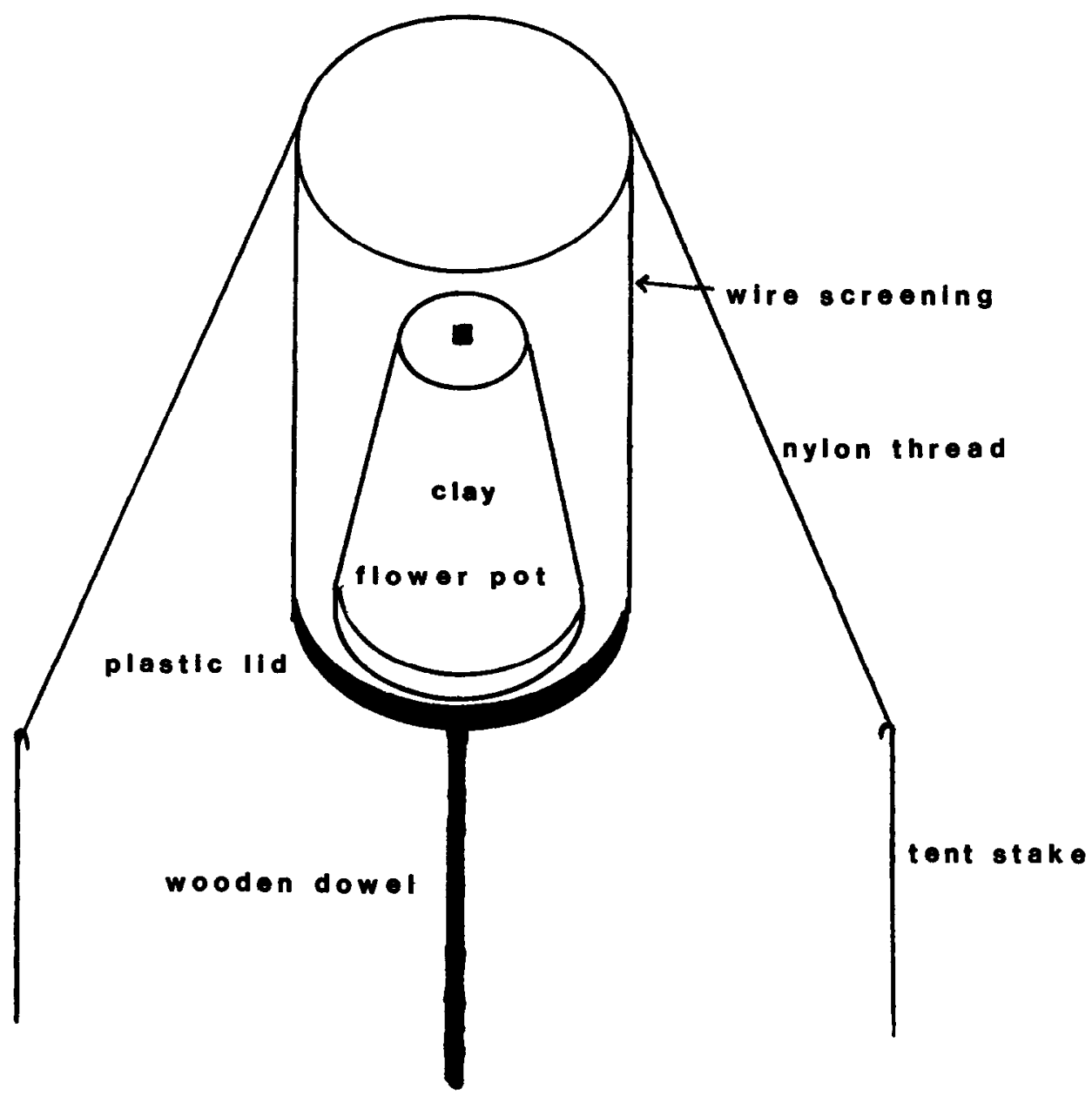

Fig. 1. Nutrient releasing substrate with grazer enclosure/exclosure

\& Lowe (1984). Algae were also observed growing on the cages and a buildup of floculent material was present inside the cages. Snails from each substrate were placed into separate whirl packs and weighed. A few small snails of species other than Elimia had invaded some of the nutrient enriched substrates; however, no other large grazers were observed. The average weight of snails on the substrates to which we added grazers was $3.85 \pm 0.47 \mathrm{~g}$ while the average weight of snails which invaded the 'ungrazed' substrates was $0.80 \pm 0.35 \mathrm{~g}$. The weight of invaded snails was small compared to the weight of introduced snails thus a significant difference in snail densities was maintained between treatments. To avoid confusion we will continue to refer to the substrates without introduced snails as ungrazed substrates.

Algae were subsampled and counted in a Palmer Maloney nanoplankton counting chamber. Ten randomly chosen fields at $450 \mathrm{X}$ magnification were counted from each replicate which yielded an average of 750 cells/sample. Nondiatom taxa were identified to species. Diatoms were enumerated in the counting chamber and were later identified to species employing $\mathrm{Hyrax}^{\circledR}$ mounts. Species densities were converted to biovolume $/ \mathrm{mm}^{2}$ in each treatment using the average biovolume of 5 random cells of each species. 


\section{Analysis}

Effects of nutrient addition and grazing on total biovolume were analyzed by two-way ANOVA's for the following treatments: low-nutrient vs. high-nutrient starting communities; low-nutrient vs. high-nutrient grazed communities; and lownutrient vs. high-nutrient ungrazed communities (Zar, 1984). In addition, variance was analyzed on total and relative biovolume for species with a relative abundance over $10 \%$ in any treatment. Relative abundance by division for each treatment was computed using average biovolumes for each species. Sorrensons Similarity index was used to compare communities. An index value of 0 indicates no populations in common and an index value of 1 indicates that the two communities are identical. Taxon diversity was measured with the index advocated by Wilhm (1968). ANOVAs were performed on the diversity values of the grazed and ungrazed treatments.

\section{Results}

\section{Overall effects of nutrients and grazing}

Algal biovolume was significantly higher in highnutrient treatments than in low-nutrient treat- ments ( $\mathrm{p}<005$ ), but was not significantly affected by grazing (Fig. 2). There was a major shift in taxonomic composition due to nutrient enrichment by the 28th day (Fig. 3). Low-nutrient treatments were dominated by diatoms (Bacillariophyceae) and high-nutrient treatments were dominated by green algae (Chlorophyceae) while blue green algae (Myxophyceae) maintained an equal proportion in high and low-nutrient regimes. There were no taxonomic shifts in periphyton at the class level due to grazing in general but there were shifts due to grazing within a given nutrient regime. These will be reported separately. Species diversity was similar in all treatments except for the nutrient-grazed treatment which was lower than all other treatments (Table 1). Four of the 7 taxa with a relative abundance greater than $10 \%$, (Oedogonium sp., Stigeoclonium tenue, Navicula

Table 1. Algal species diversity index values of ungrazed and grazed periphyton communities grown in high and low nutrients.

\begin{tabular}{lll}
\hline & $\begin{array}{l}\text { Low-nutrient } \\
\text { substrates }\end{array}$ & $\begin{array}{l}\text { High-nutrient } \\
\text { substrates }\end{array}$ \\
\hline Start & 3.0 & 3.58 \\
Ungrazed & 3.36 & 3.42 \\
Grazed & 2.59 & 1.10 \\
\hline
\end{tabular}

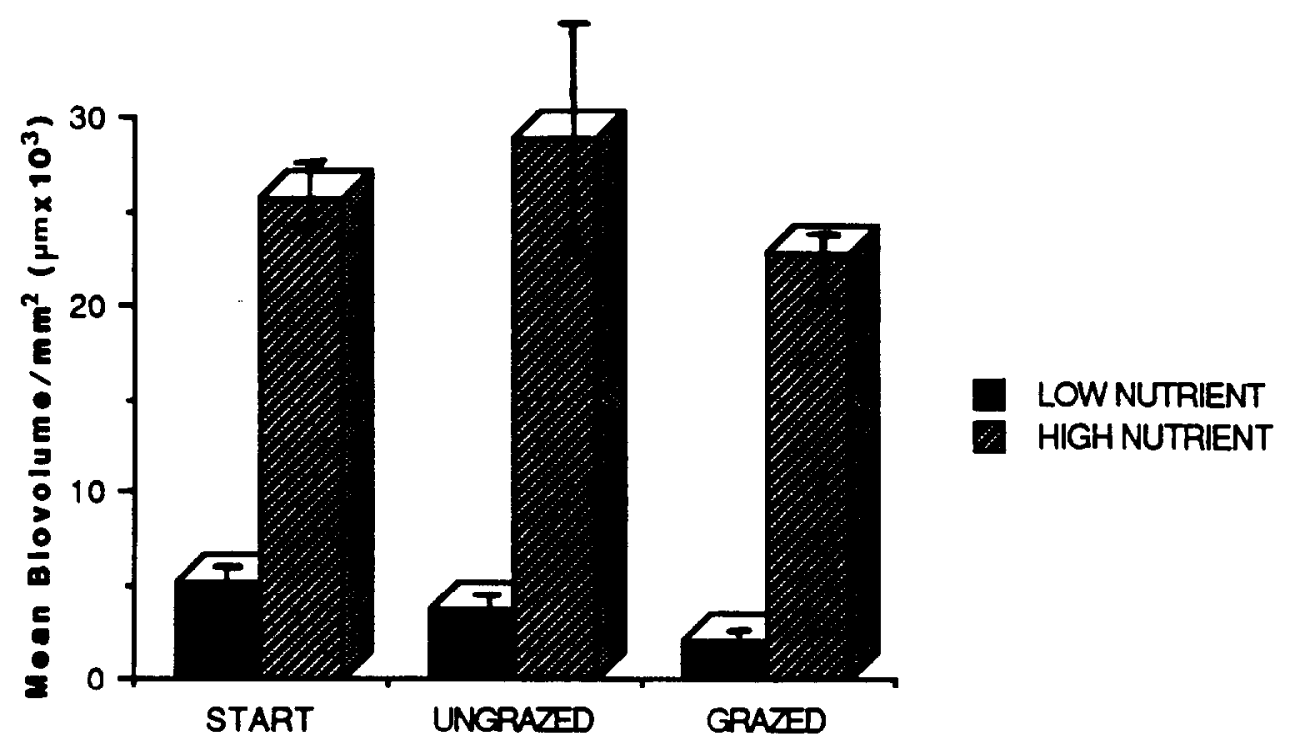

Fig. 2. Mean algal biovolume from three replicates per treatment. Starting, low nutrient, high nutrient, ungrazed, and grazed treatments are as described in text. Vertical bars denote one standard error from the mean. 


\section{Low-Nutrient Treatment}
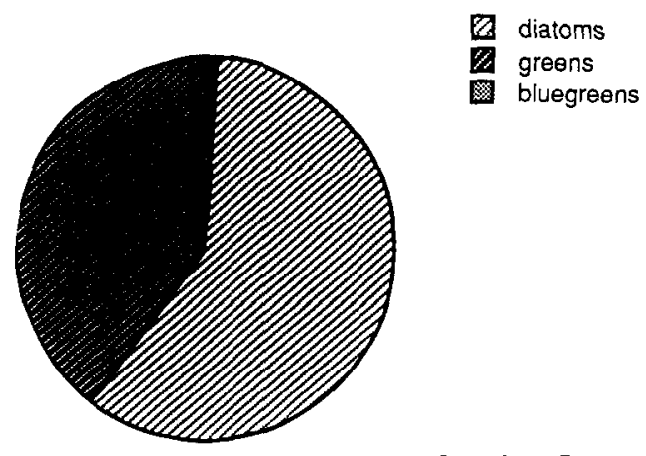

\section{High-Nutrient Treatment}

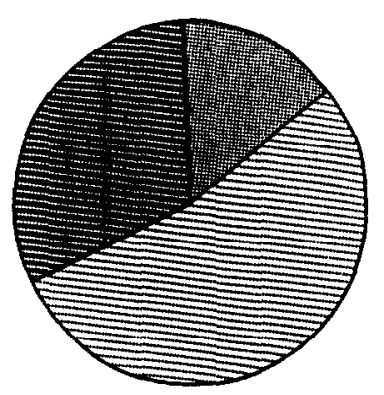

Starting Communities

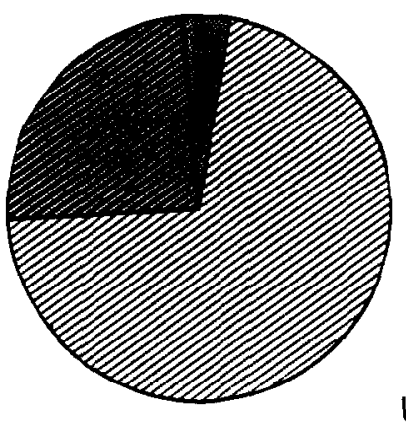

Ungrazed Communities
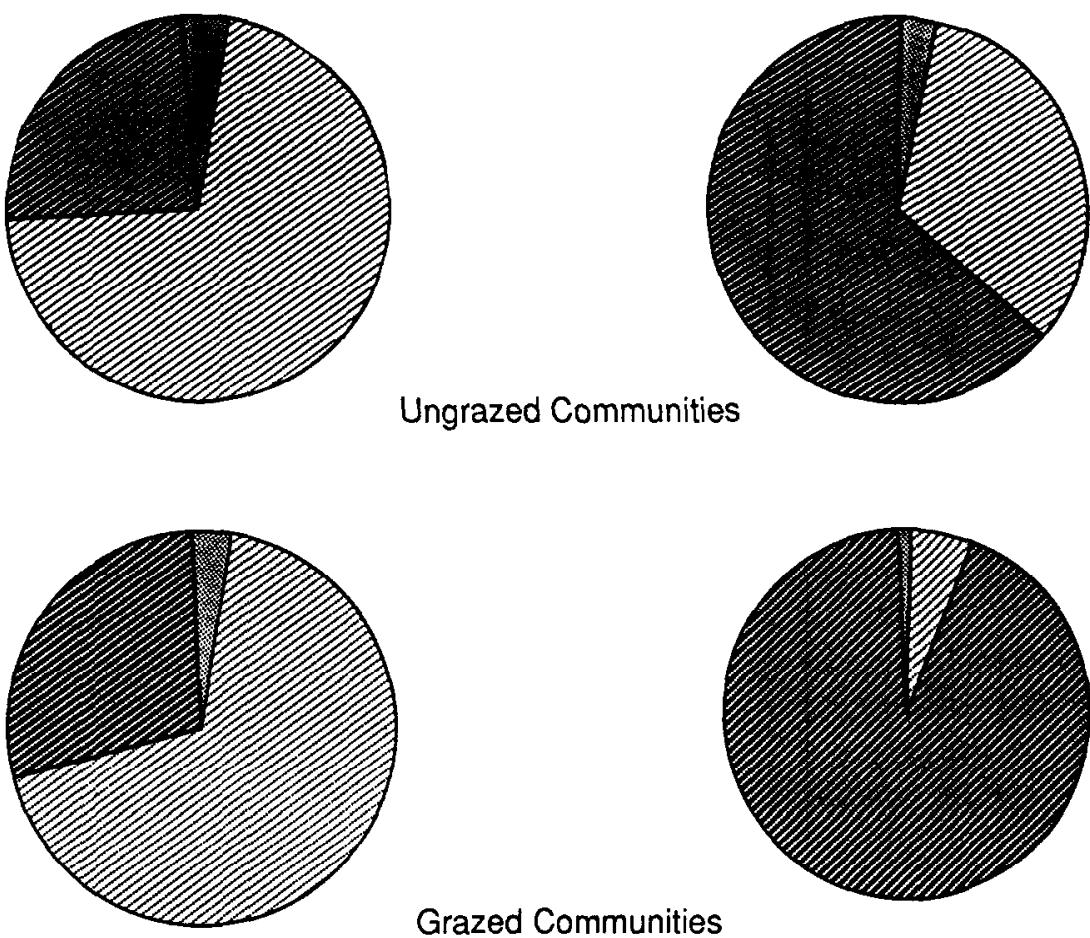

Grazed Communities radiosa var radiosa, Navicula radiosa var tenella), showed significantly $(\mathrm{p}<05)$ higher relative abundances in high-nutrient communities. Only one taxon (Navicula radiosa var radiosa) showed a significant decrease due to grazing pressure. One species (Stigeoclonium tenue) showed an increase in relative abundance due to grazing.
Comparisons within low-nutrient treatments

\section{Grazing effects}

Low-nutrient grazed treatments had slightly lower biomass than the ungrazed treatments but the difference was not statistically significant (Fig. 2). Communities did not show a change in taxonomic 
composition at the class level due to grazing (Fig. 3). Grazing caused a slight decrease in species diversity (Table 1 ).

\section{Temporal (successional) trends}

There was no temporal shift at the class level (Fig. 3). Diatoms dominated both the starting community and the ungrazed community. Sorrenson's Similarity Index was used to evaluate similarity between starting communities, grazed communities and ungrazed communities. Comparisons of similarity index values (Table 2 ) reveal that the grazed and ungrazed treatments are the most similar to each other with a similarity index value of 0.50 . The index value for the starting community vs ungrazed community is 0.33 . This is the lowest value found in the three comparisons.

\section{Comparisons within high-nutrient treatments}

\section{Grazing effects}

Grazing did not cause a significant decrease in total biomass, but did affect the taxonomic composition of the high-nutrient treatments. The relative abundance of green algae increased from $63.8 \%$ to $93.0 \%$ due to grazing (Fig. 3). Grazing also significantly $(\mathrm{P}<0.05)$ reduced species diversity (Table 1). The species diversity value for the high-nutrient ungrazed treatment was 3.42 , compared to 1.10 for the grazed treatment. Both the shift in taxonomic composition and the

Table 2. Similarity index values of periphyton community structure comparisons within a given nutrient regime. Based on Sorrenson's Similarity Index: $0=$ no similarity, 1 = complete overlap.

\begin{tabular}{ll}
\hline & Similarity index value \\
\hline Low-nutrient treatments & \\
$\quad$ Start vs. ungrazed & 0.33 \\
Start vs. grazed & 0.45 \\
Grazed vs. ungrazed & 0.51 \\
High-nutrient treatments & \\
$\quad$ Start vs. ungrazed & 0.11 \\
Start vs. grazed & 0.06 \\
Grazed vs. ungrazed & 0.66 \\
\hline
\end{tabular}

decrease in diversity are due to the increase in relative abundance of Stigeoclonium tenue on the grazed substrates. Stigeoclonium increased in total biomass on the grazed substrates. The increase is not statistically significant but it indicates that Stigeoclonium is not reduced under grazer pressure. It was the only major taxon which was not reduced by grazing.

Stigeoclonium has both prostate basal cells and erect filamentous cells. These were counted separately in order to see if grazing effects the two morphologies differently. The relative abundance of basal cells increased significantly in the grazer treatment. The relative abundance of erect filamentous cells was similar in both treatments. The ratio of basal cells: filamentous cells increased slightly from 4.7 in the ungrazed treatments to 5.2 in the grazed treatments.

\section{Temporal trends}

The taxonomic composition of both the starting grazed and ungrazed communities changed over time (Fig. 3). Diatoms were the most abundant class in the starting communities $(54.5 \%)$. Blue green algae were more abundant in the starting community than in the ungrazed community. Green algae dominated the ungrazed community. This dominance was also due primarily to Stigeoclonium increasing in relative abundance from less than $1 \%$ to $62 \%$ between days 18 and 28.

Comparisons of the similarity index values for all pairs of the nutrient treatments showed that the grazed and ungrazed communities were the most similar to each other (0.66) (Table 2). Similarity between the starting community and both the grazed and ungrazed substrates was low. Thus the starting community had very little overlap in species composition with either the grazed or ungrazed communities.

\section{Discussion}

Nutrient levels had a pronounced effect both on total biovolume and on class composition. This corroborates the findings of Cuker (1983) on 
periphyton and Vanni (1987) on plankton. Species diversity, however, was not affected by the nutrient regime. All communities except the high-nutrient grazed community had a relatively high level of species diversity. This is because most species were present in low abundance. Only 7 of the 52 species present had relative abundances over $10 \%$ in any of the treatments.

The high relative abundance of green filamentous algae in the high-nutrient treatments substantiates findings by Fairchild et al. (1985). Many green algae are well adapted to highnutrient regimes. They are strong competitors for light and space (Lowe et al., 1986; Shortreed \& Stockner, 1983). When nutrients are abundant they can grow rapidly and dominate communities. As in this study, Fairchild et al. (1985) working in Douglas Lake found that Stigeoclonium tenue dominated nutrient enriched substrates. In his survey of literature pertaining to algal pollution tolerance Palmer (1969) listed Stigeoclonium tenue as the 6th most tolerant species of algae to organic pollution. In addition, studies done on algae in streams subject to eutrophication by pig farms shown an abundance of Stigeoclonium (Francke \& Den Oude, 1983). Thus the dominance of Stigeoclonium in nutrient rich communities is well documented.

\section{Low-nutrient treatment}

Grazing had little effect on the biovolume, diversity or taxonomic structure of low-nutrient communities. Most of the species within the lownutrient treatments had low relative abundance. Because ANOVA's were only performed on taxa with at least a $10 \%$ relative abundance, the effect of grazing on most of the rare taxa was undetected in this analysis. In addition, the shading effect of the cages probably further reduced growth in these communities which were consistently low in algal biovolume. Consequently, the snails could have been preferentially feeding on algae growing on the cages which would have decreased the effects of grazing on the substrates.

The relative lack of species similarity between the starting community and the ungrazed community represents a major shift in community structure. However, these differences were not reflected in the relative abundances of algal classes. This illustrates that although the same relative proportions of major classes of algac persist in low-nutrient conditions thru time, the species within these classes differ in relative abundance as succession proceeds. The relatively high similarity value for the comparison between grazed and ungrazed treatments indicates that temporal effects were more profound than grazer effects in this experiment. This suggests that despite possible physiological similarities between grazed communities and early successional communities (Hunter, 1980; McMahon et al., 1974) the similarity does not extend to species composition.

\section{High-nutrient treatment}

Grazers did not significantly decrease biovolume on nutrient enriched substrates. The fact that grazers did not significantly affect biovolume in any of our experimental treatments may seem initially surprising in light of previous grazing experiments (Dickman, 1968 etc., Kehde \& Wilhm, 1972; Summer \& McIntire, 1982), and may be due to an insufficient density of snails to crop the nutrient stimulated periphyton. Grazing did, however, cause a decrease in diversity. Grazing also caused an increase in dominance by green algae due to the increase in relative abundance of Stigeoclonium on grazed substrates. These findings support those of Lubchenco (1978) who proposed that in rocky intertidal habits grazers will decrease diversity if they have a minimal negative effect, or a positive effect on the biomass of the dominant species. The high-nutrient communities exhibited a temporal change in taxonomic composition. This temporal difference was greater than that shown in the low-nutrient communities and is clearly a function of stimulating resource-limited algal populations that are normally of restricted distribution in Douglas Lake. The low-nutrient substrates experienced 
ambient lake nutrient levels whereas the highnutrient substrates provided a very different microhabitat. Those species which were adapted to the low-nutrient substrates are abundant in the lake whereas those species which were adapted to the high-nutrient conditions have fewer natural microhabitats. Thus it would take more time for nutrient-adapted species to colonize this microhabitat. The initial abundance of bluegreen algae in the high-nutrient starting community suggests that bluegreen algae are able to take advantage of high-nutrient levels but are unable to compete for light and space once green filaments begin to dominate.

The increase in relative abundance of Stigeoclonium tenue basel calls under grazing pressure corroborates the recent results of grazing experiments in artificial streams (Lamberti et al., 1987; Steinman et al., 1987), which reported that grazed algal assemblages were dominated by basal cells and short filaments of Stigeoclonium tenue. Our results reinforce the ideas of Steinman et al. (1987), who hypothesized that the heterotrichous growth form of Stigeoclonium tenue has adaptive significance. It is likely that the prostate basal cells are small enough and adhere tightly enough to the substrate to resist being grazed. Once grazing pressure is reduced these cells would then be able to generate an erect filamentous growth form.

Comparisons of similarity index values between high-nutrient communities show the same trends as those between low-nutrient communities. Grazed and ungrazed communities are the most similar. Neither are similar to the starting community. Thus it appears that grazers do not maintain communities in a taxonomically early successional stage.

\section{Conclusion}

Nutrient enrichment had a more pronounced effect on altering community composition than did grazing. Grazers effected nutrient enriched and unenriched communities differently. Grazing did not significantly reduce biomass in either case. This effect might have been dampened by experimental problems. In low-nutrient communities grazers had little effect on diversity and relative abundance of major classes. Grazers did, however, alter species composition. In nutrient enriched communities grazing decreased diversity and caused a shift in relative abundance of major classes. In neither case did grazers maintain the species composition of the communities at an early successional stage.

\section{Acknowledgements}

This research was conducted in part as a project for the Naturalist and Ecologist Training Program at the University of Michigan. We thank Craig Layne, Molly Dougherty, Dan Freidus, Barry Rosen, Hunter Carrick, John Rotenberry, G. W. Fairchild, and Reno Van Valkenburgh for their help with this project. We would also like to thank the participants in the NETP program for helpful comments and insights.

\section{References}

Cattaneo, A., 1987. Periphyton in lakes of different trophy. Can. J. Fish. aquat. Sci. 44: 296-302.

Cuker, B. E., 1983. Grazing and nutrient interactions in controlling the activity and composition of the epilithic algal community of an arctic lake. Limnol. Oceanogr. 28: 133-141.

Dickman, M., 1968. The effect of grazing by tadpoles on the structure of a periphyton community. Ecol. 49: 1188-1190.

Fairchild, G. W. \& R. L. Lowe, 1984. Artificial substrates which release nutrients: Effects on periphyton and invertebrate succession. Hydrobiologia 114: 29-37.

Fairchild, G. W., R. L. Lowe \& W. B. Richardson, 1985. Algal periphyton growth on nutrient-diffusing substrates: An in situ bioassay. Ecology 66: 465-472.

Francke, J. A. \& P. J. Den Oude, 1983. Growth of Stigeoclonium and Ooedogonium species in artificial ammonium$\mathbf{N}$ and phosphate-P gradients. Aquat. Bot. 15: 375-380.

Hoagland, K. D., S. C. Roemer \& J. R. Rowsowski, 1982. Colonization and community structure of two periphyton assemblages, with emphasis on the diatoms (Bacillariophyceae). Am. J. Bot. 69: 188-213.

Huntcr, R. D., 1980. Effects of grazing on the quantity and quality of freshwater aufwuchs. Hydrobiologia 69: 251-259.

Hunter, R. D. \& W. D. Russell-Hunter, 1983. Bioenergetic 
and community changes in intertidal aufwuchs grazed by Littorina littorea. Ecology 64: 761-769.

Kehde, P. M. \& J. L. Wilhm, 1972. The effects of grazing by snails on community structure of periphyton in laboratory streams. Am. Midl. Nat. 87: 8-24.

Lamberti, G. A. \& V. H. Resh, 1983. Stream periphyton and insect herbivores: An experimental study of grazing by a caddisfly population. Ecology 64: 1124-1135.

Lamberti, G. A., L. R. Ashkenas, S. V. Gregory \& A. D. Steinman, 1987. Effects of three herbivores on periphyton communities in laboratory streams. J. N. Am. Benthol. Soc., 6: 92-104.

Loeb, S. L., J. E. Reuter \& C. R. Goldman, 1983. Littoral zone production of oligotrophic lakes: The contributions of phytoplankton and periphyton. In Wetzel, R. G. (ed.). Periphyton of freshwater ecosystems. Dr. W. Junk Publishers, The Hague. ISBN 906193 . 868X: 161-167.

Lowe, R. L., S. W. Golladay \& J. R. Webster, 1986. Periphyton response to nutrient manipulation in streams draining clearcut and forested water sheds. J. N. Am. Benthol. Soc., 5: 221-229.

Lubchenco, J., 1978. Plant species diversity in a marine intertidal community: Importance of herbivore food preference and algal competitive abilities. Am. Nat. 112: 23-39.

McMahon, R. F., R. D. Hunter \& W. D. Russell-Hunter, 1974. Variation in aufwuchs at six freshwater habitats in terms of carbon biomass and of carbon; nitrogen ratio. Hydrobiol. 45: 391-404.

Palmer, C. M., 1969. A composite rating of algae tolerating organic population. J. Phycol. 5: 78-82.

Shortreed, K. R. S. \& J. G. Stockner, 1983. Periphyton biomass and species composition in a coastal rainforest stream in British Columbia: effects of environmental changes caused by logging. Can. J. Fish. and aquat. Sci. 40 : 1887-1895.

Steinman, A. D., C. D. McIntire, S. V. Gregory, G. A. Lamberti \& L. R. Ashkenas, 1987. Effects of herbivore type and density on taxonomic structure and physiognomy of algal assemblages in laboratory streams. J. N. Am. Benthol. Soc. 6: 175-188.

Sumner, W. T. \& C. D. McIntire, 1982. Grazer-periphyton interactions in laboratory streams. Arch. Hydrobiol. 93: 135-157.

Vanni, M. J., 1987. Effects of nutrients and zooplankton size on the structure of a phytoplankton community. Ecology 68: 624-635.

Wetzel, R. G., 1964. A comparative study of primary productivity of higher aquatic plants, periphyton and phytoplankton in a large shallow lake. Int. Rev. Gesamten Hydrobiol. 49: 1-61.

Wilhm, J. L., 1968. Use of biomass units in Shannon's formula. Ecology 49: 153-156.

Zat, J. H., 1984. Biostatical Analysis, 2nd ed. Prentice-Hall, Inc., Englewood Cliffs, NJ. 717 pp. 